\title{
Clinical use of aclidinium in patients with COPD
}

This article was published in the following Dove Press journal:

International Journal of COPD

28 April 2014

Number of times this article has been viewed

\author{
Debra J Reid \\ Alexa A Carlson \\ Department of Pharmacy Practice, \\ Northeastern University, School \\ of Pharmacy, Boston, MA, USA
}

Correspondence: Debra J Reid Department of Pharmacy Practice, Northeastern University, 360 Huntington Avenue, R218TF,

Boston, MA 02115, USA

$\mathrm{Tel}+\mathrm{I} 6173737719$

Fax + I 6173737655

Email d.reid@neu.edu
Abstract: Chronic obstructive pulmonary disease (COPD) is the sixth-leading cause of death in the US. The Global Initiative for Chronic Obstructive Lung Disease (GOLD) guidelines provide evidence-based recommendations for the clinical management of chronic COPD. Longacting inhaled bronchodilators continue to be the mainstay of current management. Aclidinium bromide (Tudorza ${ }^{\mathrm{TM}}$ Pressair $^{\mathrm{TM}}$ ) joins tiotropium as a long-acting inhaled antimuscarinic bronchodilator approved by the US Food and Drug Administration for the maintenance treatment of COPD. Early studies demonstrated aclidinium's significant bronchodilatory effects supporting once-daily dosing; however, two Phase III studies, Aclidinium Clinical Trial Assessing Efficacy and Safety in Moderate to Severe COPD Patients (ACCLAIM/COPD) I and ACCLAIM/COPD II, in which patients were randomized to receive aclidinium $200 \mu \mathrm{g}$ daily, failed to achieve the minimal clinically important difference in improvement of trough forced expiratory volume in 1 second $\left(\mathrm{FEV}_{1}\right)$, suggesting the need for higher doses or more frequent dosing. Additional studies - Aclidinium to Treat Airway Obstruction in COPD Patients (ATTAIN) and Aclidinium in Chronic Obstructive Respiratory Disease (ACCORD) I - were undertaken to compare 200 and $400 \mu \mathrm{g}$ twice-daily dosing. The mean improvements from baseline in trough $\mathrm{FEV}_{1}$ in the $400 \mu \mathrm{g}$ groups were $+129 \mathrm{~mL}$ over 24 weeks and $+124 \mathrm{~mL}$ over 12 weeks in ATTAIN and ACCORD I, respectively. Aclidinium also had beneficial effects on health-related quality of life and other endpoints, such as rescue medication use and rates of exacerbations. Aclidinium bromide inhalation powder is generally well tolerated in patients with COPD, with headache, cough, diarrhea, and rhinosinusitis among the most commonly reported adverse events. Cardiovascular side effects were rarely reported. Patient satisfaction studies found that patients using the aclidinium delivery device had fewer errors affecting drug delivery than those using the tiotropium device and, overall, the aclidinium device was preferred to the tiotropium device. In conclusion, aclidinium bromide is approved for use in the US at a dose of $400 \mu \mathrm{g}$ twice daily and is a promising alternative to tiotropium.

Keywords: chronic obstructive pulmonary disease, aclidinium, antimuscarinic, anticholinergic

\section{Introduction}

Chronic obstructive pulmonary disease (COPD) comprises a group of respiratory conditions that includes emphysema and chronic bronchitis. ${ }^{1,2}$ Most patients with COPD exhibit features of both chronic bronchitis and emphysema; differentiation is no longer considered relevant. ${ }^{2} \mathrm{COPD}$ is characterized by chronic inflammation that causes airway remodeling and parenchymal destruction, leading to persistent airflow limitation that is usually progressive. ${ }^{3}$ The resulting features are decline of expiratory flow and inadequate lung emptying on expiration. Exacerbations and comorbidities also contribute to the severity of the disease. ${ }^{2}$ 
In 2008, COPD moved from the sixth- to the third-leading cause of death in the US. ${ }^{1}$ This increase is thought to have been driven by the aging population, smoking epidemic, and reduced mortality from other common causes of death. ${ }^{4}$ Data analyzed from a 2011 Behavioral Risk Factor Surveillance System survey suggest that $6.3 \%$ of US adults (an estimated 15 million) have been diagnosed with the disease. ${ }^{1}$

The Global Initiative for Chronic Obstructive Lung Disease (GOLD) guidelines provide evidence-based recommendations for the clinical management of chronic COPD. Smoking cessation is the most important intervention and all patients who smoke should be encouraged to quit. The goals of pharmacologic treatment are to reduce symptoms and exacerbations and improve exercise tolerance and health status. Long-acting inhaled bronchodilators, which include the long-acting beta-adrenoceptor agonists salmeterol, formoterol, arformoterol, and indacaterol, and the long-acting muscarinic receptor antagonist tiotropium continue to be the mainstay of the current management of COPD. The choice of agent is patient specific and should consider availability, cost, and delivery device, including the patient's ability to effectively use the device. ${ }^{2}$ Aclidinium bromide (Tudorza ${ }^{\mathrm{TM}}$ Pressair ${ }^{\mathrm{TM}}$; Almirall, SA, Barcelona, Spain) is the second long-acting inhaled antimuscarinic bronchodilator to have been approved by the US Food and Drug Administration (FDA) for maintenance treatment of COPD. ${ }^{5}$ This article reviews the pharmacology, pharmacokinetics, efficacy, safety, and place in therapy of aclidinium bromide.

\section{Data selection}

A search of PubMed was performed using the search terms "chronic obstructive pulmonary disease", "aclidinium", "anticholinergic", and "muscarinic receptor antagonist" to identify the relevant literature. References from each identified article were reviewed for applicable articles. US government websites, including the FDA's and the ClinicalTrials.gov database, and references from identified sources were also reviewed.

\section{Pharmacology}

The superfamily of G-protein-coupled receptors includes five subtypes of the muscarinic receptors, but only $M_{1}, M_{2}$, and $M_{3}$ are expressed in human lung tissue. $M_{3}$ receptors are located in the smooth muscle of the airways and are primarily responsible for the bronchoconstrictor response to cholinergic nerve stimulation. Antagonism of the muscarinic receptors, particularly $\mathrm{M}_{3}$, mediates bronchodilation and smooth-muscle relaxation. $\mathrm{M}_{2}$ receptors are also expressed in the heart, the antagonism of which is theorized to cause bronchoconstriction and tachycardia. ${ }^{6,7}$ Aclidinium bromide is a potent inhibitor of all muscarinic receptors, exhibiting kinetic selectivity for the $M_{3}$ receptor (with a 29.2-hour residence half-life) comparable to that of tiotropium. Aclidinium is unique in that it dissociates from $\mathrm{M}_{2}$ receptors (with a 4.7-hour residence half-life) more than three times faster than tiotropium, thereby minimizing the potential for cardiovascular side effects. ${ }^{7}$ In animal studies, aclidinium demonstrated an onset of action twice as fast as that of tiotropium and a long duration of action similar to that of tiotropium. ${ }^{7,8}$

\section{Pharmacokinetics and pharmacodynamics}

A Phase I study of 30 healthy individuals was conducted to assess the pharmacokinetics of aclidinium bromide $200 \mu \mathrm{g}$, $400 \mu \mathrm{g}$, and $800 \mu \mathrm{g}$ twice daily (BID). Aclidinium bromide exhibited linear and time-independent pharmacokinetics. Steady state was achieved within the 7-day treatment period and was estimated to have been reached as early as the first day of treatment. ${ }^{9}$ The results from this study confirm findings from a previous study done with aclidinium at the same doses given once daily. ${ }^{10}$ In comparison, tiotropium requires $2-3$ weeks to reach steady state. ${ }^{11,12}$ Aclidinium is rapidly converted to inactive alcohol and acid metabolites, resulting in low systemic exposure, which minimizes the potential for side effects. ${ }^{9}$ Although no formal drug interaction studies have been conducted, in vitro studies suggest low potential for drug-drug interactions. No relevant CYP450 involvement was noted in studies. Another small Phase I study of 24 participants with varying degrees of renal function demonstrated no clinically significant differences in pharmacokinetics. ${ }^{13}$ Aclidinium bromide has not been studied in patients with hepatic impairment.

\section{Clinical trials}

Multiple randomized controlled trials have assessed the efficacy of aclidinium in patients with COPD. ${ }^{11,14-24}$ Inclusion criteria for the majority of studies include patients diagnosed with moderate to severe COPD $(80 \%>$ forced expiratory volume in 1 second $\left.\left[\mathrm{FEV}_{1}\right] \geq 30 \%\right), \geq 40$ years of age, with a history of cigarette smoking ( $\geq 10$ pack-years). The majority of studies included similar exclusion criteria of other pulmonary disease, COPD exacerbation or respiratory-tract infection in the past 6 weeks ( 3 months if hospitalized), unstable 
cardiac conditions, and contraindication to anticholinergic therapy. The studies allowed patients to continue on some concomitant COPD medications, including inhaled corticosteroids, systemic corticosteroids (prednisone $\leq 10 \mathrm{mg}$ daily or $\leq 20 \mathrm{mg}$ every other day), and methylxanthines. A summary of the efficacy trials can be found in Table 1.

An initial dose-ranging study in 17 adults compared aclidinium 100, 300, and $900 \mu \mathrm{g}$ with placebo. ${ }^{14}$ Following aclidinium administration, investigators found statistically significant bronchodilatory effects of the drug as early as 15 minutes, peak effect by 2 hours, and mean change from baseline $\mathrm{FEV}_{1}$ at 24 hours of $+30 \mathrm{~mL},+133 \mathrm{~mL},+131 \mathrm{~mL}$, and $-28 \mathrm{~mL}$ for aclidinium 100, 300, $900 \mu \mathrm{g}$, and placebo, respectively. This 24-hour improvement compared with placebo suggested the appropriateness of once-daily dosing. A randomized, double-blind, Phase IIb study compared aclidinium at doses of $25,50,100,200$, and $400 \mu \mathrm{g}$ with placebo and open-label tiotropium $18 \mu \mathrm{g}$ daily over a 4-week period. ${ }^{15}$ The primary efficacy endpoint of trough $\mathrm{FEV}_{1}$ of aclidinium 200 and $400 \mu \mathrm{g}$ was shown to be statistically significantly superior to placebo at week 4 at $+148 \mathrm{~mL}(P=0.006)$ and $+128 \mathrm{~mL}(P=0.018)$, respectively, achieving similar results to tiotropium $(+151 \mathrm{~mL}, P=0.003)$. Similar results were found in a double-blind, double-dummy, multicenter, crossover study comparing tiotropium $18 \mu \mathrm{g}$, placebo, and aclidinium $200 \mu \mathrm{g} .{ }^{16}$ In this study, similar increases in $\mathrm{FEV}_{1}$ at 30 minutes and over 3 hours occurred between aclidinium and tiotropium, both of which were statistically superior to placebo. Results from these studies supported the initial dose of aclidinium $200 \mu \mathrm{g}$ daily.

Aclidinium Clinical Trial Assessing Efficacy and Safety in Moderate to Severe COPD Patients (ACCLAIM/COPD) I and ACCLAIM/COPD II were two Phase III double-blind placebo-controlled trials performed over a 52-week period in which patients were randomized to aclidinium $200 \mu \mathrm{g}$ or placebo daily in a patient population with an average age of 62 years and a mean baseline $\mathrm{FEV}_{1}$ of $50 \%-55 \%$ predicted value. ${ }^{17}$ The primary efficacy endpoint, trough $\mathrm{FEV}_{1}$, was increased in the aclidinium bromide group compared with placebo by $+61 \mathrm{~mL}$ and $+63 \mathrm{~mL}$ at 12 weeks and $+67 \mathrm{~mL}$ and $+59 \mathrm{~mL}$ at 28 weeks in ACCLAIM/COPD I and ACCLAIM/COPD II, respectively ( $P<0.001$ for all). This level of bronchodilation was maintained throughout the 52-week study, with both trials showing superiority over placebo at reported time points. However, these values do not meet the minimal clinically important difference (MCID) score of $100 \mathrm{~mL}$ for $\mathrm{FEV}_{1}$ in COPD, suggesting suboptimal therapy. ${ }^{25}$ The St George's Respiratory Questionnaire
(SGRQ), a self-administered health-status questionnaire, was also assessed and scores were significantly improved in the aclidinium groups compared with placebo in both studies. For ACCLAIM/COPD I, the mean improvement from baseline SGRQ scores was -4.63 versus -3.10 for aclidinium and placebo, respectively $(P=0.19)$; similar treatment differences were noted for ACCLAIM/COPD II (-3.49 vs -1.28, $P=0.021)$. These improvements in SGRQ scores were associated with statistically significantly more patients in both treatment arms achieving the MCID of -4 units on the SGRQ. ${ }^{26}$ Further, statistically significantly more patients achieved the MCID for the Transitional Dyspnea Index (TDI) of 1 unit in both aclidinium groups compared with placebo. ${ }^{27}$ The authors concluded that aclidinium is effective in patients with moderate to severe COPD. ${ }^{17}$ However, the low trough FEV , values in this study were below the MCID, and are lower than those found in studies of tiotropium, which suggests the need for higher doses or more frequent dosing.

Based on the $\mathrm{FEV}_{1}$ results of the Phase III studies, new dose-ranging studies were completed. A Phase IIa study compared aclidinium $400 \mu \mathrm{g}$ BID with placebo and tiotropium. ${ }^{11}$ The primary efficacy endpoint of mean change in $\mathrm{FEV}_{1}$ area under the curve (AUC) $)_{0-12 / 12 \mathrm{~h}}$ on day 15 was significantly higher in the aclidinium and tiotropium groups compared with in the placebo $(+221 \mathrm{~mL}$ and $+244 \mathrm{~mL}$, respectively, $P<0.0001)$. Similar improvements were noted in trough $\mathrm{FEV}_{1}$ on day 15 for aclidinium and tiotropium groups versus placebo $(+186 \mathrm{~mL},+150 \mathrm{~mL}, P<0.0001)$ and in reduction of rescue medication use. On day 15 , aclidinium had significantly greater improvements in $\mathrm{FEV}_{1} \mathrm{AUC}_{12-24 / 24 \mathrm{~h}}$ $(P<0.05)$ and forced vital capacity (FVC) AUC $_{12-24 / 24 h}$ $(P<0.05)$ compared with tiotropium, suggesting better evening bronchodilation associated with the second dose of aclidinium. Supporting this finding was the significant improvements in evening symptom scores for the aclidinium group versus the placebo group, unlike for the tiotropium group versus placebo group. Results of this trial were supported by a Phase IIb study comparing aclidinium 100, 200, and $400 \mu \mathrm{g}$ BID with placebo and formoterol $12 \mu \mathrm{g}$ BID in patients with moderate to severe COPD over a 7-day period. ${ }^{18}$ The primary efficacy endpoint of $\mathrm{FEV}_{1} \mathrm{AUC}_{0-12}$ on day 7 compared with placebo for aclidinium 100, 200, $400 \mu \mathrm{g}$, and formoterol $12 \mu \mathrm{g}$ BID was $+154 \mathrm{~mL},+176 \mathrm{~mL},+208 \mathrm{~mL}$, and $+210 \mathrm{~mL}$, respectively $(P<0.0001$ for all $)$, with aclidinium $400 \mu \mathrm{g}$ producing statistically significant improvements compared with $100 \mu \mathrm{g}(P<0.01)$. All active control medications produced significantly greater improvements in $\mathrm{FEV}_{1} \mathrm{AUC}_{12-24}$ compared with placebo, with formoterol 

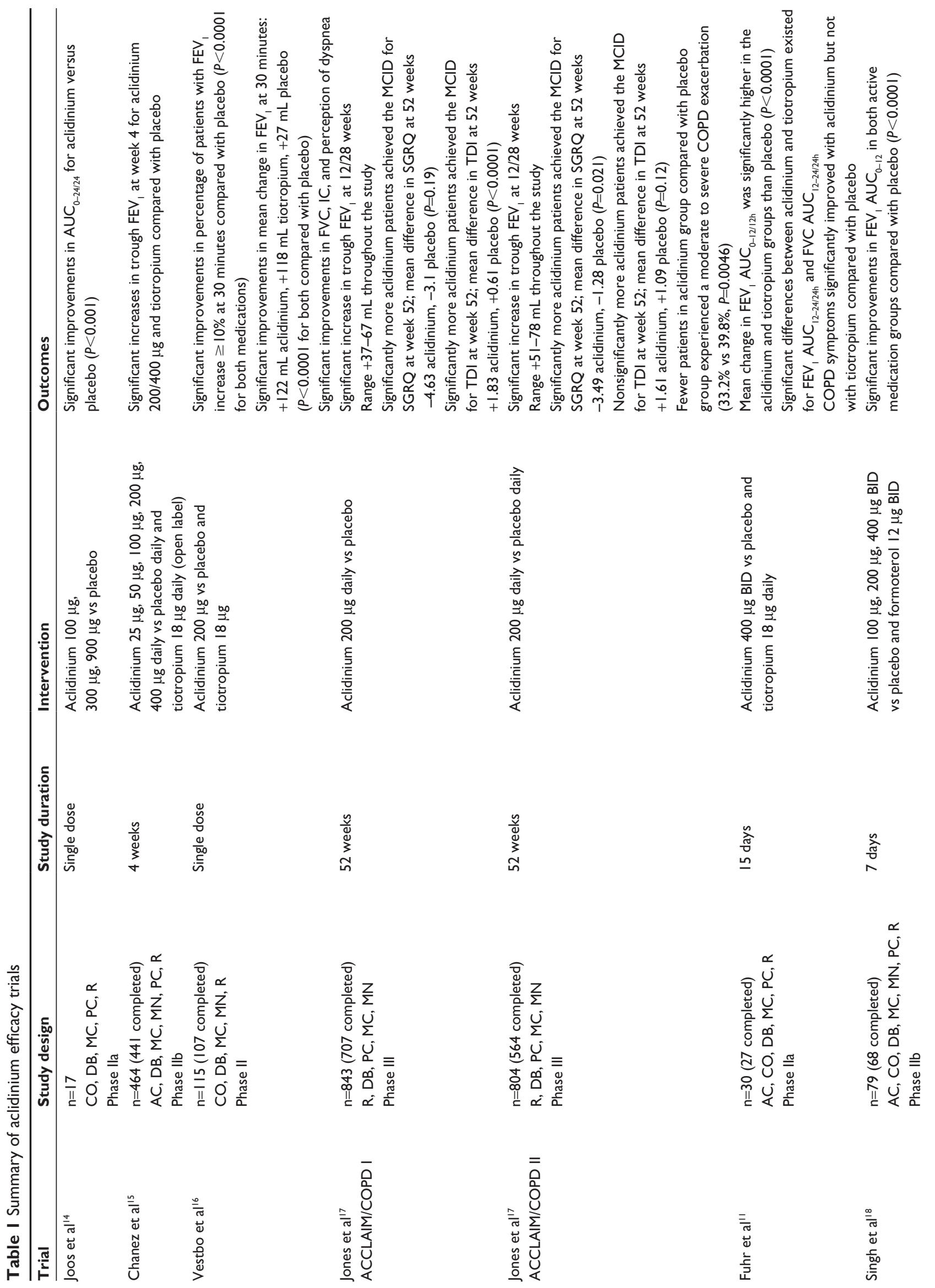

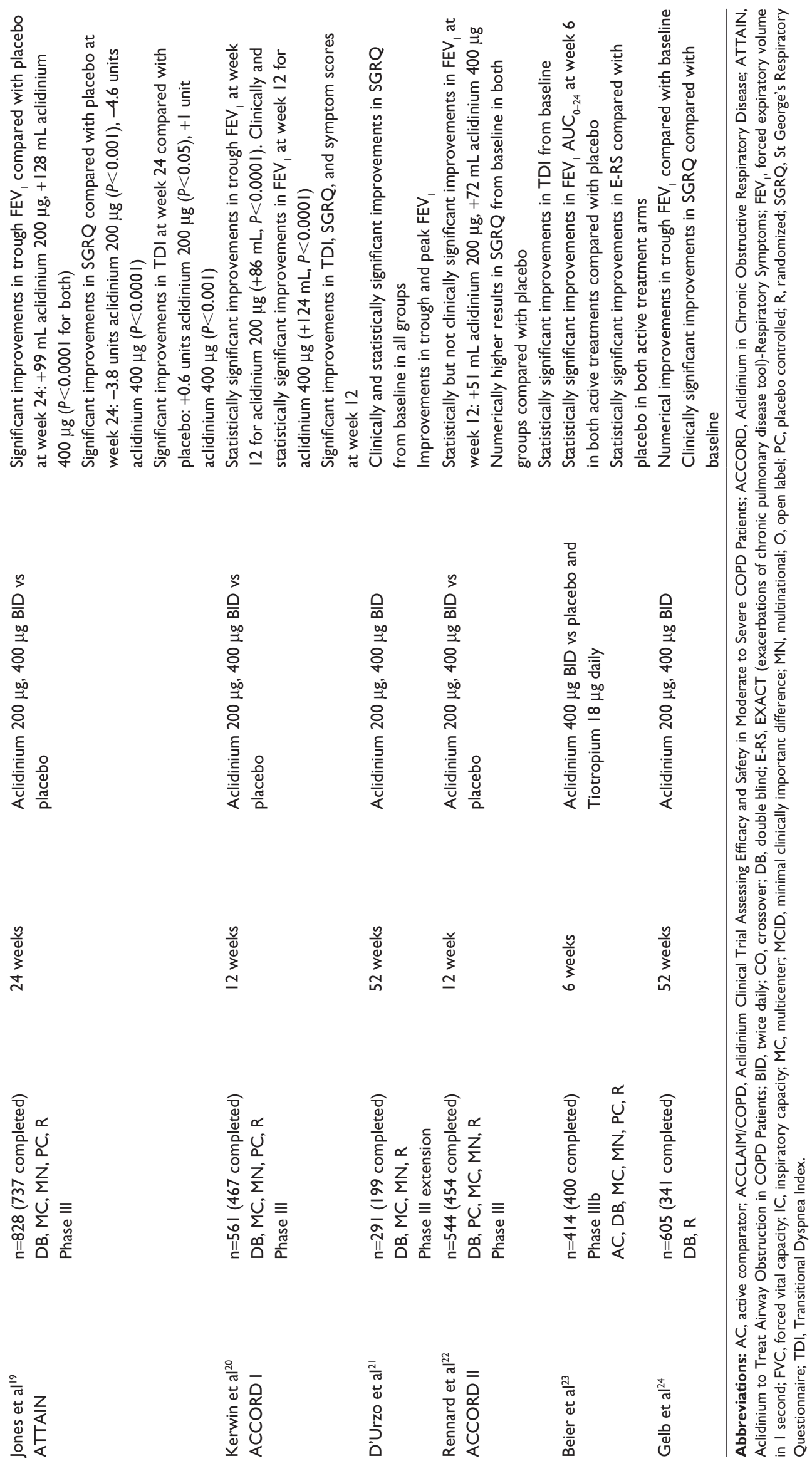

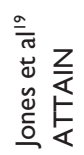



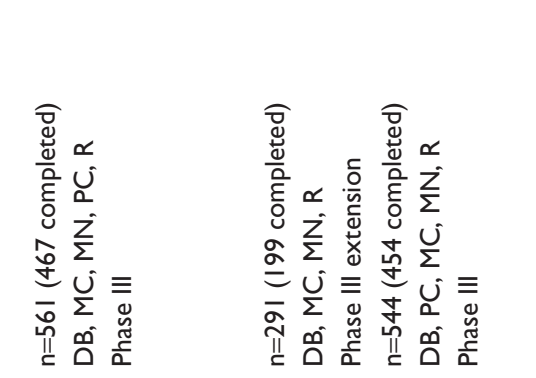

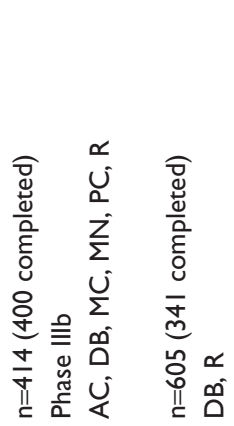

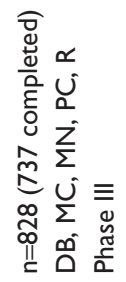

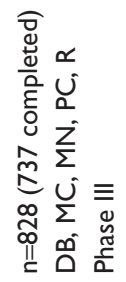

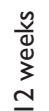

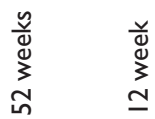



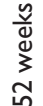

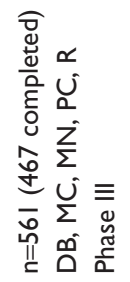

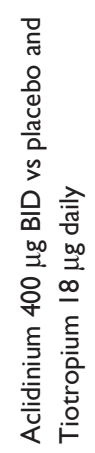






$+56 \mathrm{~mL}$ compared with aclidinium $400 \mu \mathrm{g}$ BID $(P<0.01)$. Trough $\mathrm{FEV}_{1}$ on day 7 was significantly greater for all active controller medications compared with placebo, with improvements of $+106 \mathrm{~mL},+114 \mathrm{~mL},+154 \mathrm{~mL}$, and $+148 \mathrm{~mL}$ for aclidinium 100, 200, 400, and formoterol $12 \mu \mathrm{g}$ BID, respectively. Results of these two studies suggested that doses of 200 and $400 \mu \mathrm{g}$ BID were appropriate for Phase III evaluation. ${ }^{11,18}$

Based on the Phase IIa/b data, a Phase III randomized, double-blind, placebo-controlled trial comparing aclidinium 200 and $400 \mu \mathrm{g}$ BID compared with placebo in moderate to severe COPD was undertaken. ${ }^{19}$ The Aclidinium to Treat Airway Obstruction in COPD Patients (ATTAIN) study consisted of primarily male subjects with an average age of $62.4 \pm 8$ years, an average smoking history of $40.2 \pm 19.8$ pack-years, $52.8 \%$ of whom were current smokers, and an average baseline $\mathrm{FEV}_{1} \%$ predicted of $52.5 \pm 14.1 \%$. Patients were well matched at baseline overall, with a SGRQ score approximately $46.3 \pm 16.8$ units and a baseline dyspnea index (BDI) of $6.8 \pm 2.1$ units. In terms of the primary efficacy endpoint, both aclidinium bromide 200 and $400 \mu \mathrm{g}$ significantly improved trough $\mathrm{FEV}_{1}$ compared with baseline at 24 weeks versus placebo $(+99 \pm 22 \mathrm{~mL}$ and $+128 \pm 22 \mathrm{~mL}$, respectively, $P<0.001$ for both). Of the two doses, only one met the MCID for this efficacy outcome, suggesting clinically significant improvement for only aclidinium $400 \mu \mathrm{g}$. This improvement in $\mathrm{FEV}_{1}$ with aclidinium $400 \mu \mathrm{g}$ was maintained throughout the study time points, with a range of +105 to $140 \mathrm{~mL}$, maintaining clinical significance. Peak FEV $_{1}$ was significantly improved at all time points for both doses, with similar FEV results at weeks 12 and 24. Both doses produced statistically significant improvements in FVC and inspiratory capacity (IC) compared with placebo at all prespecified time points. Both doses of aclidinium provided statistically significant improvements in health status over the 24-week period, with a mean change of $-3.8 \pm 1.1$ versus $-4.6 \pm 1.1$ units in SGRQ scores for aclidinium 200 and $400 \mu \mathrm{g}$, respectively, which met the MCID. A lower proportion of patients met the MCID in the placebo compared with the aclidinium 200 and $400 \mu \mathrm{g}$ groups $(41 \%, 56 \%$, and $57.3 \%$, respectively, $P<0.001$ for aclidinium compared with placebo). Similar to the results for the SGRQ, both aclidinium 200 and $400 \mu \mathrm{g}$ improved TDI scores by $+0.6 \pm 0.3$ units $(P<0.05)$ and $+1 \pm 0.3$ units $(P<0.001)$, respectively, with the $400 \mu \mathrm{g}$ dose meeting MCID for clinical significance. This increase in health status was paralleled by a significant reduction in the use of rescue medication for both doses of aclidinium compared with placebo. Further, reductions in the rate ratio of COPD exacerbations of any severity was significantly lower with aclidinium 200 (rate ratio $=0.72,95 \%$ confidence interval $[\mathrm{CI}]=0.52-0.99$ ) and $400 \mu \mathrm{g}$ (rate ratio $=0.67,95 \% \mathrm{CI}=0.48-0.94$ ) compared with placebo, despite the study not being powered specifically for exacerbations.

Similar to the ATTAIN study, the Aclidinium in Chronic Obstructive Respiratory Disease (ACCORD) I study, a Phase III, randomized, double-blind, placebo-controlled trial over 12 weeks, compared aclidinium 200 and $400 \mu \mathrm{g}$ BID with placebo in patients with moderate to severe COPD. ${ }^{20}$ The subjects had an average age of $64.2 \pm 9.4$ years, $53 \%$ were male, and $44.8 \%$ were current smokers with a smoking history of $54.3 \pm 26.8$ pack-years. Baseline $\mathrm{FEV}_{1}$ was $47.2 \% \pm 14.1 \%$ predicted, an average baseline SGRQ of $46.5 \pm 17.1$ units and BDI of $6.4 \pm 2.1$ units. For the primary efficacy outcomes, aclidinium $200 \mu \mathrm{g}$ statistically significantly increased trough $\mathrm{FEV}_{1}$ at 12 weeks ( $+86 \mathrm{~mL}, P<0.0001$ ), while aclidinium $400 \mu \mathrm{g}$ both clinically and statistically significantly increased trough $\mathrm{FEV}_{1}(+124 \mathrm{~mL}, P<0.0001)$. In addition, both doses were associated with significant improvements in peak $\mathrm{FEV}_{1}$ at 12 weeks ( $+146 \mathrm{~mL},+192 \mathrm{~mL}, P<0.0001$ for both). Both IC and mean $\mathrm{FVCAUC}_{0-3 / 3 \mathrm{~h}}$ statistically significantly improved from baseline compared with placebo at the end of 12 weeks. In the first week, maximal bronchodilation was achieved and maintained throughout the study. Mean improvements in SGRQ scores compared with placebo at 12 weeks were -2.7 units in aclidinium $200 \mu \mathrm{g}(P=0.013)$ and -2.5 units in aclidinium $400 \mu \mathrm{g}(P=0.019)$, meeting statistical but not clinical significance. Similarly, statistically significant improvements were found for both doses at week 12 in the TDI score, with aclidinium $400 \mu \mathrm{g}$ achieving clinical significance. Nonvalidated questionnaires developed by the sponsor specifically for this study were utilized to assess changes in symptoms and rescue medication use. Compared to placebo, aclidinium 200 and $400 \mu \mathrm{g}$ produced significant improvements in daily symptoms at 12 weeks, with aclidinium $400 \mu \mathrm{g}$ numerically higher than $200 \mu \mathrm{g}$. Aclidinium $200 \mu \mathrm{g}$ did not meet statistical significance in improvement of nighttime breathing and nighttime sputum production, where the $400 \mu \mathrm{g}$ dose also did not meet statistical significance in improvement in sputum production. Both doses of aclidinium were associated with significant reductions in rescue medication use at the end of the 12-week period. Both doses of aclidinium were associated with significant reductions in rescue medication use at the end of the 12-week period. Similar to the ATTAIN study, a reduction in rates of COPD exacerbations of any kind with aclidinium 200 and $400 \mu \mathrm{g}$ compared with placebo was demonstrated, with $0.55,0.41$, and 0.79 exacerbations, 
respectively, resultant per patient year. Only the comparison of the $400 \mu \mathrm{g}$ dose with placebo demonstrated a significant reduction in rates of exacerbations of any kind (rate ratio $=0.52, P=0.009)$.

In a 1-year extension of the ACCORD I study, the patients assigned originally to placebo were randomized (1:1) to either aclidinium 200 or $400 \mu \mathrm{g}$ and active medication patients continued their current dose of aclidinium for 52 weeks. ${ }^{21}$ At the end of the treatment period, patients on continuous aclidinium 200 and $400 \mu \mathrm{g}$ had a trough $\mathrm{FEV}_{1}$ change from baseline of $+69 \mathrm{~mL}$ and $+56 \mathrm{~mL}$, respectively. For patients re-randomized from placebo to aclidinium, improvements were seen in $\mathrm{FEV}_{1}$ similar to those seen in the initial ACCORD I study, although results were not reported. Clinically and statistically significant improvements in SGRQ scores occurred at 52 weeks in the continuous aclidinium group, with a mean improvement of -7.0 units in $200 \mu \mathrm{g}$ and -7.9 units in the $400 \mu \mathrm{g}$ group. In patients changed from placebo to aclidinium, clinically and statistically significant improvements in SGRQ scores also occurred, with improvements of -4.9 units in the $200 \mu \mathrm{g}$ group and -5.7 units in the $400 \mu \mathrm{g}$ group. All groups also experienced reduced use of rescue medication for the treatment of COPD symptoms.

A third Phase III randomized, double-blind, placebocontrolled trial in patients with moderate to severe COPD comparing aclidinium 200 and $400 \mu \mathrm{g}$ with placebo over a 12-week period, ACCORD II, was undertaken to confirm results of previous trials. ${ }^{22}$ This study was performed in patients with an average age of $62.8 \pm 8.9$ years and $53.1 \%$ of subjects were male. Approximately $53.3 \%$ of patients were current smokers, with a 53.8 \pm 29.1 pack-year history. Baseline pulmonary function showed an $\mathrm{FEV}_{1}$ of $52.5 \% \pm 13.4 \%$ predicted, a baseline SGRQ score of $49 \pm 17.6$ units, and TDI of $6.2 \pm 2.1$ units. Two patients in the placebo group had mild COPD and one patient in the aclidinium $200 \mu \mathrm{g}$ group had very severe COPD discovered after randomization. Additionally, an uneven dispersion of patients with moderate and severe COPD existed between the placebo and both aclidinium groups, with more moderate COPD favored in the placebo group and more severe COPD in the aclidinium $400 \mu \mathrm{g}$ group. The primary efficacy endpoint of trough $\mathrm{FEV}_{1}$ at 12 weeks was statistically but not clinically significantly superior to placebo, with an improvement of $+51 \mathrm{~mL}$ and $+72 \mathrm{~mL}$ for aclidinium 200 and $400 \mu \mathrm{g}$ BID, respectively ( $P<0.05$ for both). Patients also showed improvements in peak $\mathrm{FEV}_{1}$, IC, and FVC from baseline in both aclidinium groups compared with placebo. Improvements in SGRQ scores were seen in all three groups, with a score of $-5.4,-6$, and -4.3 units for aclidinium $400 \mu \mathrm{g}$, $200 \mu \mathrm{g}$, and placebo, respectively. TDI improved with aclidinium 200 and $400 \mu \mathrm{g}$ by +1.0 and +1.3 units from baseline compared with +0.3 units with placebo $(P<0.05$ compared with placebo for both aclidinium groups). This minimal improvement in outcomes may be attributed to the uneven patient dispersion among COPD severity groups favoring the placebo group and thereby minimizing the treatment effect. Numerically, less use of rescue medication occurred in the aclidinium groups compared with in the placebo group.

Patients with moderate to severe COPD were assessed in a Phase IIIb trial comparing aclidinium $400 \mu \mathrm{g}$ BID, tiotropium $18 \mu \mathrm{g}$ daily, and placebo. ${ }^{23}$ This study included patients with an average age of $\sim 62$ years and post-bronchodilator $\mathrm{FEV}_{1}$ of $55 \%-56 \%$ predicted, with $\sim 53 \%$ current smokers with a 39.5-45.0 pack-year history of smoking depending on group. The primary efficacy outcome of $\mathrm{FEV}_{1} \mathrm{AUC}_{0-24}$ at week 6 in both aclidinium and tiotropium groups significantly improved compared with placebo $(+150 \mathrm{~mL},+140 \mathrm{~mL}$, respectively, $P<0.0001$ for both). At week 6, numerically greater change in $\mathrm{FEV}_{1} \mathrm{AUC}_{12-24}$ in aclidinium $(+160 \mathrm{~mL})$ compared with tiotropium $(+123 \mathrm{~mL})$, similar to previous Phase II studies demonstrating superior bronchodilatory activity of aclidinium in the evening was observed. ${ }^{11}$ Tiotropium had numerically greater $\mathrm{FEV}_{1} \mathrm{AUC}_{0-12}$ compared with aclidinium, although this did not meet statistical significance. ${ }^{23}$ Symptoms were assessed using the Exacerbations of Chronic Pulmonary Disease Tool (EXACT), a 14-item instrument. Responses for 11 of the 14 questions were used to calculate another score called the "EXACT-Respiratory Symptoms" (E-RS) score, in which higher numbers are associated with increased symptoms on a scale from 0 to 40 . At week 6 , a significant improvement in E-RS score occurred with both tiotropium and aclidinium compared with placebo, $P<0.05$ and $P<0.0001$, respectively. Similar to previous Phase II studies, and in accordance with the $\mathrm{FEV}_{1} \mathrm{AUC}_{12-24}$, aclidinium, but not tiotropium, led to a significant reduction in nighttime symptom severity compared with placebo. ${ }^{11}$ However, differences in symptom scores between active treatment groups were not significant. ${ }^{23}$

A 52-week study in patients with moderate to severe COPD compared aclidinium 200 and $400 \mu \mathrm{g}$ BID in patients with a mean age of 63.6 years and mean post-bronchodilator $\mathrm{FEV}_{1}$ of $52.3 \%$ predicted. ${ }^{24}$ In this study, mean improvements in trough $\mathrm{FEV}_{1}$ at 52 weeks of $+34 \mathrm{~mL}$ and $+72 \mathrm{~mL}$ in the 200 and $400 \mu \mathrm{g}$ aclidinium groups, respectively, were observed. At week 52, mean improvements in SGRQ scores were clinically significant, with -5.3 units and -5.2 units 
in the 200 and $400 \mu \mathrm{g}$ groups, respectively, compared with baseline. Although no clinically significant improvements in $\mathrm{FEV}_{1}$ were reached at week 52, the numerical improvement along with the results from the previous Phase III trials support the FDA-approved dose of aclidinium $400 \mu \mathrm{g}$ BID.

\section{Safety}

Aclidinium studies with doses of up to $6,000 \mu \mathrm{g}$ have shown that aclidinium is safe. ${ }^{10}$ Further studies of up to $900 \mu \mathrm{g}$ inhaled have demonstrated that there are minimal amounts of the medication in the blood after administration. ${ }^{14}$ After doses of 100,300 , and $900 \mu \mathrm{g}$, the amount of active medication and alcohol-based metabolite were both below the lower limit of quantification of $<0.1 \mathrm{ng} / \mathrm{mL}$ in the blood at all time points. ${ }^{14}$ The inactive acid metabolite was detected at a few time points after the $300 \mu \mathrm{g}$ dose, and, after the $900 \mu \mathrm{g}$ dose, the maximum concentration was detected at 3 hours after dosing with a concentration between 3 and $6 \mathrm{ng} / \mathrm{mL} .{ }^{14}$ This promotes a reduction in rates of both adverse events and the potential for drug interactions. As a long-acting muscarinic antagonist, aclidinium has the propensity for side effects, including dry mouth, constipation, and increased risk of urinary-tract infections. Of the clinical studies available, few of the reported anticholinergic adverse events have been directly associated with aclidinium bromide. The most common side effects of aclidinium include headache, nasopharyngitis, cough, and diarrhea. ${ }^{5}$

Muscarinic antagonist activity at the $\mathrm{M}_{2}$ receptor has been associated with the potential for cardiovascular adverse events associated with muscarinic antagonists. Results of a meta-analysis performed by Singh et al raised concerns for adverse cardiovascular events associated with tiotropium use. ${ }^{28}$ Data from the Understanding Potential Long-term Impacts on Function with Tiotropium (UPLIFT) trial, which compared tiotropium $18 \mu \mathrm{g}$ daily with placebo over a 4-year treatment period, found no significant difference in mortality between tiotropium and placebo in the intention-to-treat analysis (hazard ratio $[\mathrm{HR}]=0.89,95 \% \mathrm{CI}=0.79-1.02$ ). ${ }^{29}$ In 67 patients compared with 85 patients in the tiotropium and placebo groups, respectively, myocardial infarction occurred (relative risk $[\mathrm{RR}]=0.71,95 \%$ CI 0.52-0.99). Similarly, stroke developed in 80 placebo patients and 82 tiotropium patients $(\mathrm{RR}=0.95 ; 95 \% \mathrm{CI}=0.70-1.29) .{ }^{29}$ Based on the currently available information, the FDA does not presently support an increased risk of stroke, myocardial infarction, or death associated with tiotropium delivered by the HandiHaler ${ }^{\circledR}$ (Spiriva ${ }^{\circledR}$ HandiHaler,
Boehringer Ingelheim Pharmaceuticals, Inc., Ridgefield, CT, USA) device. ${ }^{30}$ As a result of these concerns, aclidinium studies have included cardiovascular safety assessments, although the drug's reduced residence time at $\mathrm{M}_{2}$ receptors and more rapid plasma hydrolysis compared with tiotropium is thought to contribute to its positive cardiovascular safety profile. $^{7}$ This is supported by the lack of significant electrocardiography changes in clinical trials and a specific safety study focusing on the effect of aclidinium on corrected QT interval (QTc). This study was a Phase I trial completed in 272 healthy patients who were randomized to placebo, aclidinium $200 \mu \mathrm{g}$, or aclidinium $800 \mu \mathrm{g}$ once daily for 3 days. Patients were also given open-label moxifloxacin $400 \mathrm{mg}$ as an active control for the treatment period. All patient groups had similar values for QT interval corrected for individual heart rate (QTcI) at baseline, with no significant changes between either aclidinium dose or placebo noted at any time period. Moxifloxacin, however, demonstrated significant increase in QTcI compared with placebo at all time points. ${ }^{31}$ Overall, cardiac-related adverse events were rare in the studies and often unrelated to the active medication.

For example, in the ATTAIN study, two incidents of cardiovascular adverse events - a myocardial infarction in a patient on $200 \mu \mathrm{g}$ aclidinium and an acute cardiac failure in a patient on aclidinium $400 \mu \mathrm{g}$ - occurred, both of which were not thought to be treatment related. ${ }^{19}$ Few adverse events occurred in the ACCORD COPD II study, five of which were cardiovascular mediated. Of these five events, four occurred in patients on placebo therapy, and one incident of tachycardia occurred in a patient on aclidinium $400 \mu \mathrm{g}$ BID. ${ }^{22}$

In the ACCORD COPD I extension study, patients were re-randomized in a 1:1 ratio to placebo: aclidinium 200 or $400 \mu \mathrm{g}$ BID, or maintained on their original dose of aclidinium 200 or $400 \mu \mathrm{g}$ BID for a 52-week period. Treatmentemergent adverse events (TEAEs) were similar across the treatment arms, with $77.4 \%$ in the aclidinium $200 \mu \mathrm{g}$ and $73.7 \%$ in the aclidinium $400 \mu \mathrm{g}$ group experiencing at least one TEAE, the most common of which were acute exacerbations of adverse events. The TEAE was determined by investigators to be attributable to aclidinium $200 \mu \mathrm{g}$ and $400 \mu \mathrm{g}$ $10.2 \%$ and $12.5 \%$ of the time, respectively. Anticholinergic side effects were uncommon, with urinary-tract infections occurring in $3.6 \%$ and $5.9 \%$ of patients taking aclidinium $200 \mu \mathrm{g}$ and $400 \mu \mathrm{g}$, respectively. Similarly, constipation occurred in $2.9 \%$ and $1.3 \%$ in aclidinium 200 and $400 \mu \mathrm{g}$ BID, respectively. Dry mouth associated with aclidinium only occurred in one patient in the $400 \mu \mathrm{g}$ group. Of the patients who experienced cardiac adverse events, only three of these 
events were considered treatment related: one patient in the $200 \mu \mathrm{g}$ group experienced acute coronary syndrome and atrial fibrillation - prior to study initiation, this patient had a cardiovascular history significant for coronary artery bypass and coronary angioplasty; one patient on aclidinium $400 \mu \mathrm{g}$ with a medical history significant for cardiac disorders had congestive heart failure; and a third patient experienced firstdegree atrial-ventricular blockade in the aclidinium $400 \mu \mathrm{g}$ group. ${ }^{21}$ Results of this study are similar to those of another 52-week study comparing aclidinium 200 and $400 \mu \mathrm{g}$ BID as well as those of other Phase III trials.

\section{Patient satisfaction}

Rates of medication nonadherence have approached 50\% for chronic disease states in developed countries. ${ }^{32}$ This has important implications for COPD patients, as medication nonadherence has been associated with increased mortality, health-care cost, and hospitalizations. ${ }^{33,34}$ Various factors have been associated with patient nonadherence, including patient-based, societal, and treatment-related factors, which can affect adherence and thus the underlying disease state. Treatment-related factors such as method of administration, ease of use, side-effect profile, and accessibility can affect patient satisfaction and, therefore, patient adherence and the proper treatment of COPD. Aclidinium bromide has been formulated in a unique breath-actuated, multi-dose drypowder inhaler (Tudorza ${ }^{\mathrm{TM}}$ Pressair $^{\mathrm{TM}}$ ) with multiple patient feedback mechanisms to promote proper use of the inhaler. These feedback mechanisms include both sound and color feedback. When activating the inhaler, a color window at the front of the inhaler turns from red to green indicating the inhaler is ready to use; once a dose has been properly inhaled, the color turns back to red. Similarly, during inhalation, when a dose is properly taken, the patient should hear a click to indicate appropriate use. ${ }^{5}$

Beier et al sought to assess inhaler preference in 414 patients through a double-blind, double-dummy, randomized, multicenter, placebo- and active-controlled study comparing aclidinium $400 \mu \mathrm{g}$ BID to tiotropium $18 \mu \mathrm{g}$ daily over a 6-week period. ${ }^{23}$ At the end of the 6-week period, overall willingness to continue on either the aclidinium Genuair $^{\mathrm{TM}}$ (Almirall SA) inhaler or tiotropium HandiHaler ${ }^{\mathrm{B}}$ inhaler was assessed based on a 0-100 scale, with higher numbers being associated with increased willingness to continue on the inhaler; overall inhaler preference was also assessed. Additionally, patient preference for either the Genuair or HandiHaler, based on specific attributes such as ease of use, ease of learning to use, operation, holding, dose preparation, and inhaler feedback indicating proper use, was analyzed. More patients at the end of the 6-week period preferred Genuair to HandiHaler, with few patients having no preference for either inhaler $(80.1 \%, 10.7 \%$, and $9.2 \%$, respectively, $P<0.0001)$. When assessing inhaler-based specific factors between Genuair and HandiHaler, Genuair was preferred in each category, as can be seen in Table 2. When assessing patient willingness to continue with a device, more patients were willing to continue with the Genuair than the HandiHaler, as indicated by a higher mean rating in the preference scale at week $6(88.8$ vs $45.4, P<0.0001){ }^{23}$

Beier et al's results are supported by an open-label, randomized, crossover study by van der Palen et al comparing patient preference and satisfaction between the aclidinium Genuair/Pressair and tiotropium HandiHaler in patients with moderate to severe COPD. ${ }^{35}$ In this 2-week, placebo-only trial, 105 patients were assessed on their satisfaction with the inhaler in terms of eight inhaler-related attributes, willingness to continue with a particular inhaler, and the number of errors related to inhaler use. Overall, patients demonstrated a higher satisfaction with Genuair than with HandiHaler (79.1\% vs $20.9 \%, P<0.0001)$. In terms of the specific inhaler attributes, significantly more patients were satisfied with and preferred Genuair to HandiHaler, as can be seen in Table 2. Although still significantly preferred compared with HandiHaler, fewer patients demonstrated satisfaction with the feedback to indicate correct dose inhalation of Genuair compared with satisfaction in other categories. When comparing the number of errors between the two inhaler types, seven patients experienced an error with Genuair compared with 19 patients with HandiHaler $(6.7 \%$ vs $18.1 \%, P<0.01)$. When comparing patients who had at least one "critical" error, defined as an error affecting drug delivery, three patients had at least one with Genuair compared with 20 patients with HandiHaler (2.9\% vs $19 \%, P<0.0001)$, excluding those patients who made errors with both inhaler types. The majority of errors with Genuair occurred during dose inhalation, with common errors being failure to hold the inhaler upright and to hold their breath for several seconds after inhalation. In terms of willingness to continue using an inhaler, as assessed on a 0-100 scale on which higher numbers indicated willingness to continue, the mean scores for Genuair were higher ( 84.0 vs 62.5, $P<0.0001)$.

An advantage of van der Palen et al's study was the use of placebo instead of active medication, which thereby limited the effect of perceived effectiveness of therapy on satisfaction results. ${ }^{35}$ This is especially important in a study comparing tiotropium and aclidinium due to the longer time 
Table 2 Patient satisfaction with Pressair ${ }^{\mathrm{TM}} / \mathrm{Genuair}^{\mathrm{TM}}$ versus HandiHaler devices

\begin{tabular}{|c|c|c|c|c|}
\hline \multirow[t]{2}{*}{ Parameter } & \multicolumn{2}{|c|}{$\begin{array}{l}\text { Beier et al, }{ }^{23} n=4 \mid 4 \\
\text { Patient preference (\%) }\end{array}$} & \multicolumn{2}{|c|}{$\begin{array}{l}\text { Van der Palen et al, }{ }^{35} \mathrm{n}=105 \\
\text { Patient preference (\%) }\end{array}$} \\
\hline & Pressair/Genuair & HandiHaler & Pressair/Genuair & HandiHaler \\
\hline Ease of use & $86.7^{*}$ & 9.0 & $83.9 *$ & 16.1 \\
\hline Convenience & $87.4^{*}$ & 7.8 & $79.8 *$ & 20.2 \\
\hline Ease of learning & $79.1^{*}$ & 8.0 & $82.4^{*}$ & 17.6 \\
\hline Ease of holding & $79.9^{*}$ & 8.5 & $85.4^{*}$ & 14.6 \\
\hline Ease of operation & $81 . I^{*}$ & 9.2 & $84.5^{*}$ & 15.5 \\
\hline Ease of dose preparation & $86.4^{*}$ & 7.8 & $87.6 *$ & 12.4 \\
\hline User feedback & $76.2^{*}$ & 9.5 & $69.2 * *$ & 30.8 \\
\hline
\end{tabular}

Notes: $* P<0.000$ I; $* * P<0.01$ compared with HandiHaler.

to steady state for tiotropium therapy. The authors concluded that the Genuair inhaler is preferred to HandiHaler by patients with moderate to severe COPD. The limitations of this trial included its small population; short duration; and exclusion of patients who would have difficulty with proper inhaler use, including patients with body malformation, unable to read, and/or with disease states that affect coordination. These exclusion criteria greatly limit the applicability of the results to patients who would have more difficulty in using inhalers properly at baseline; as such, further studies in this area are needed. ${ }^{35}$

Similar results were found in a Phase IIb trial comparing aclidinium 100, 200, and $400 \mu \mathrm{g}$ BID to placebo and formoterol $12 \mu \mathrm{g}$ BID. When patients' preference for the Genuair versus Foradil Aerolizer $^{\mathbb{R}}$ (Novartis AG, Basel, Switzerland) devices was assessed, more patients demonstrated preference for the Genuair ( $75.6 \%$ vs $10.3 \%)$ and found the inhaler easier to use. ${ }^{18}$

\section{Conclusion}

GOLD guidelines recommend long-acting inhaled bronchodilators for the first-line treatment of COPD. Until recently, tiotropium was the only long-acting muscarinic receptor antagonist available for use in the US. Although limited headto-head trials comparing the efficacy and safety of tiotropium and aclidinium have been conducted, placebo-controlled trials show they are comparable in terms of improving lung function and health status in patients with moderate to severe COPD. Clinical studies suggest a good safety profile and low incidence of both anticholinergic side effects and medication-related cardiovascular events. The adverse events most commonly reported with aclidinium use were headache, cough, diarrhea, and rhinosinusitis. Cardiovascular side effects were rarely reported in two extension trials and one dedicated safety study (all of 52 weeks' duration). Postmarketing studies will be conducted to further determine the risk of potential cardiovascular side effects.
The choice of agent should also consider patient preference for dosing schedule and administration. Once-daily dosing would be expected to be the preferred option, however, studies that examined patient satisfaction found the aclidinium delivery device was preferred to the tiotropium device. Aclidinium's feedback mechanisms appear to reinforce proper administration with fewer administration errors compared with the tiotropium inhaler.

Aclidinium bromide, a long-acting muscarinic antagonist, is approved for use in the US at a dose of $400 \mu \mathrm{g}$ BID for the maintenance treatment of COPD. It is a promising alternative to tiotropium, having demonstrated similar efficacy and safety in several clinical trials. Future studies will likely include products that combine muscarinic receptor antagonists and long-acting beta-adrenoceptor agonists in one device.

\section{Disclosure}

The authors report no conflicts of interest in this work.

\section{References}

1. Centers for Disease Control and Prevention (CDC). Chronic obstructive pulmonary disease among adults - United States, 2001. MMWR e Mortal Wkly Rep. 2012;61(46):938-943.

2. Global Initiative for Chronic Obstructive Lung Disease (GOLD). Global Strategy for the Diagnosis, Management and Prevention of COPD (GOLD) 2013. Available from: http://www.goldcopd. org/uploads/users/files/GOLD_Report_2014_Jan23.pdf. Accessed January 28, 2014.

3. Williams DM, Bourdet SV. Chronic obstructive pulmonary disease. In: DiPiro JT, Talbert RL, Yee GC, Matze GR, Wells BG, Posey ML, editors. Pharmacotherapy: A Pathophysiologic Approach. 8th ed. New York, NY: McGraw-Hill; 2011:471-496. Available from: http:// www.accesspharmacy.com/content.aspx?aID=7975888. Accessed November 15, 2013.

4. Chapman KR, Mannino DM, Soriano JB, et al. Epidemiology and costs of chronic obstructive pulmonary disease. Eur Respir J. 2006;27(1):188-207.

5. Tudorza ${ }^{\mathrm{TM}}$ Pressair $^{\mathrm{TM}}$ (aclidinium bromide inhalation powder) [product information]. St Louis, MO: Forest Pharmaceuticals, Inc.; 2012. Available from: http://www.frx.com/pi/tudorza_pi.pdf. Accessed on March 6, 2014. 
6. Belmonte K. Cholinergic pathways in the lungs and anticholinergic therapy for chronic obstructive pulmonary disease. Proc Am Thorac Soc. 2005;2(4):297-304.

7. Gavaldà A, Miralpeix M, Ramos I, et al. Characterization of aclidinium bromide, a novel inhaled muscarinic antagonist, with long duration of action and a favorable pharmacological profile. J Pharmacol Exp Ther. 2009;331(2):740-751.

8. Prat M, Fernández D, Buil MA, et al. Discovery of novel quaternary ammonium derivatives of (3R)-quinuclidinol esters as potent and long-acting muscarinic antagonists with potential for minimal systemic exposure after inhaled administration: identification of (3R)-3-\{[hydroxy(di-2-thienyl)acetyl]oxy\}-1-(3-phenoxypropyl)-1azoniabicyclo[2.2.2] octane bromide (aclidinium bromide). JMed Chem . 2009;52(16):5076-5092.

9. Lasseter K, Dilzer S, Jansat JM, Garcia Gil E, Caracta CF, Ortiz S. Safety and pharmacokinetics of multiple doses of aclidinium bromide administered twice daily in healthy volunteers. Pulm Pharmacol Ther. 2012;25(2):193-199.

10. Jansat JM, Lamarca R, Gil EG, Ferrer P. Safety and pharmacokinetics of single doses of aclidinium bromide, a novel long-acting, inhaled antimuscarinic, in healthy subjects. Int $J$ Clin Pharmacol Ther. 2009;47(7):460-468

11. Fuhr R, Magnussen H, Sarem K, et al. Efficacy of aclidinium bromide $400 \mu \mathrm{g}$ twice daily compared with placebo and tiotropium in patients with moderate to severe COPD. Chest. 2012;141(3): 745-752.

12. Spiriva ${ }^{\circledR}$ HandiHaler ${ }^{\circledR}$ (tiotropium bromide inhalation powder) [product information]. Ridgefield, CT: Boehringer Ingelheim Pharmaceuticals, Inc.; 2013.

13. Schmid K, Pascual S, Gil EG, Ortiz S, Jansat JM. Pharmacokinetics and safety of aclidinium bromide, a muscarinic antagonist, in adults with normal or impaired renal function: A phase I, open-label, single-dose clinical trial. Clin Ther. 2010;32(10):1798-1812.

14. Joos GF, Schelfhout VJ, Pauwels RA, et al. Bronchodilatory effects of aclidinium bromide, a long-acting muscarinic antagonist, in COPD patients. Respir Med. 2010;104(6):865-872.

15. Chanez P, Burge PS, Dahl R, et al. Aclidinium bromide provides longacting bronchodilation in patients with COPD. Pulm Pharmacol Ther. 2010;23(1):15-21.

16. Vestbo J, Vogelmeier C, Creemers J, Falques M, Ribera A, Gil EG. Onset of effect of aclidinium, a novel, long-acting muscarinic antagonist, in patients with COPD. COPD. 2010;7(5):331-336.

17. Jones PW, Rennard SI, Agusti A, et al. Efficacy and safety of oncedaily aclidinium in chronic obstructive pulmonary disease. Respir Res. 2011;12:55.

18. Singh D, Magnussen H, Kirsten A, et al. A randomised, placebo- and active-controlled dose-finding study of aclidinium bromide administered twice a day in COPD patients. Pulm Pharmacol Ther. 2012;25(3): 248-253.

19. Jones PW, Singh D, Bateman ED, et al. Efficacy and safety of twicedaily aclidinium bromide in COPD patients: the ATTAIN study. Eur Respir J. 2012;40(4):830-836.
20. Kerwin EM, D’Urzo AD, Gelb AF, Lakkis H, Garcia Gil E, Caracta CF ACCORD I study investigators. Efficacy and safety of a 12-week treatment with twice-daily aclidinium bromide in COPD patients (ACCORD COPD I). COPD. 2012;9(2):90-101.

21. D’Urzo A, Kerwin E, Rennard S, He T, Gil EG, Caracta C. One-year extension study of ACCORD COPD I: safety and efficacy of two doses of twice-daily aclidinium bromide in patients with COPD. COPD. 2013;10(4):500-510.

22. Rennard SI, Scanlon PD, Ferguson GT, et al. ACCORD COPD II: a randomized clinical trial to evaluate the 12-week efficacy and safety of twice-daily aclidinium bromide in chronic obstructive pulmonary disease patients. Clin Drug Investig. 2013;33(12):893-904.

23. Beier J, Kirsten A, Mróz R, et al. Efficacy and safety of aclidinium bromide compared with placebo and tiotropium in patients with moderate-to-severe chronic obstructive pulmonary disease: results from a 6-week, randomized, controlled Phase IIIb study. COPD. 2013;10(4):511-522.

24. Gelb AF, Tashkin DP, Make BJ, Zhong X, Garcia Gil E, Caracta C; LAS-MD-35 study investigators. Long-term safety and efficacy of twice-daily aclidinium bromide in patients with COPD. Respir Med. 2013;107(12):1957-1965.

25. Donohue JF. Minimal clinically important differences in COPD lung function. COPD. 2005;2(1):111-124.

26. Jones PW. St George's Respiratory Questionnaire: MCID. COPD. 2005;2(1):75-79.

27. Mahler DA, WItek TJ Jr. The MCID of the transition dyspnea index is a total score of one unit. COPD. 2005;2(1):111-124.

28. Singh S, Loke YK, Furberg CD. Inhaled anticholinergics and risk of major adverse cardiovascular events in patients with chronic obstructive pulmonary disease: a systematic review and meta-analysis. JAMA. 2008;300(12):1439-1450.

29. Tashkin DP, Celli B, Senn S, et al; UPLIFT Study Investigators. A 4-year trial of tiotropium in chronic obstructive pulmonary disease. N Engl J Med. 2008;359(15):1543-1554.

30. Michele TM, Pinheiro S, Iyasu S. The safety of tiotropium - the FDA's conclusions. N Engl J Med. 2010;363(12):1097-1099.

31. Lasseter KC, Aubets J, Chuecos F, Gil EG. Aclidinium bromide, a longacting antimuscarinic, does not affect QT interval in healthy subjects. J Clin Pharmacol. 2011;51(6):923-932.

32. World Health Organization (WHO). Adherence to Long-term Therapies Evidence for Action. Geneva: WHO; 2003. Available from: http://www. who.int/chp/knowledge/publications/adherence_report/en/. Accessed January 29, 2014.

33. Bourbeau J, Bartlett SJ. Patient adherence in COPD. Thorax. 2008;63(9): 831-838.

34. Vestbo J, Anderson JA, Calverley PM, et al. Adherence to inhaled therapy, mortality and hospital admission in COPD. Thorax. 2009;64(11): 939-943.

35. Van der Palen J, Ginko T, Kroker A, et al. Preference, satisfaction and errors with two dry powder inhalers in patients with COPD. Expert Opin Drug Deliv. 2013;10(8):1023-1031.
International Journal of COPD

\section{Publish your work in this journal}

The International Journal of COPD is an international, peer-reviewed journal of therapeutics and pharmacology focusing on concise rapid reporting of clinical studies and reviews in COPD. Special focus is given to the pathophysiological processes underlying the disease, intervention programs, patient focused education, and self management protocols.

\section{Dovepress}

This journal is indexed on PubMed Central, MedLine and CAS. The manuscript management system is completely online and includes a very quick and fair peer-review system, which is all easy to use. Visi http://www.dovepress.com/testimonials.php to read real quotes from published authors. 